\title{
Franchising for the social sector
}

\author{
Olav Sorenson ${ }^{1}$ (D)
}

Received: 14 August 2021 / Accepted: 16 September 2021 / Published online: 27 September 2021

(c) The Author(s) 2021

\begin{abstract}
This essay discusses the organizational design of Unjani Clinics as described in Szerb, Kivleneice, and Aggarwal's organizational zoo case study.
\end{abstract}

Keywords Franchising · Incentives · Organizational design · Social sector

After emerging from the darkness of Apartheid, South Africa's citizens did not simply amend the old constitution. They wrote a new one, a better one. This willingness to abandon the status quo in South Africa has created an environment ripe for innovation, particularly in the social sector and in organizational design. Unjani Clinics is one of these experiments.

South Africa has a two-tiered health system. Its private hospitals provide some of the best health care in the world. The public system, meanwhile, has chronic shortages of doctors, especially in rural areas. Many people must travel long distances even for the treatment of common ailments.

Unjani Clinics has sought to solve this problem by creating a chain of clinics, owned, managed, and staffed by nurses. These clinics do not depend on the short supply of doctors. They can nevertheless handle many common health issues at affordable prices and in places closer to those in need of their services. If Unjani succeeds in its goal of opening more than a thousand locations by 2030 , it not only would provide direct health care to millions, but also could improve the public health system, by triaging patients and allowing public facilities to concentrate their limited resources on those with the most dire need.

What type of organizational "animal" should we consider Unjani Clinics to be? Szerb, Kivleneice, and Aggarwal call it a social franchise. That label seems apt.

Olav Sorenson

olav.sorenson@anderson.ucla.edu

1 UCLA Anderson School of Management, 110 Westwood Plaza, Los Angeles, CA 90095, USA
Franchises represent something between a set of subsidiaries and a gaggle of independent entrepreneurs (e.g., Caves and Murphy 1976). They have four key features:

1. Franchisees receive rights to use a name and sell a particular set of products and services.

2. The franchisor typically gives its franchisees training and assistance in beginning their operations, and maintains some services shared by the chain (such as advertising and purchasing certain supplies).

3. In exchange, franchisees pay a royalty to the franchisor.

4. But franchisees remain responsible for operating their businesses and retain any residual profits that they generate.

Unjani Clinics appears to have all of these attributes. Their nursepreneurs receive the right to use the Unjani brand name and to provide a defined set of services. Unjani helps them start their clinics, providing training and equipment. The nursepreneurs pay Unjani a fee in exchange, but remain responsible for the profit and loss of their businesses.

Although we often associate franchising with restaurants and hotels, this form of organization has been used in a variety of settings. Many business services, for example, have been organized as franchises. It has also been used extensively and in innovative ways in South Africa. South African Breweries ( $\mathrm{SAB}$ ), for instance, has essentially organized its entire distribution system as a franchise, with owner-drivers managing each route. Franchising has even been common in the world of non-profit organizations (Oster 1992).

Franchises have become popular, in part, because they solve an organizational problem. Companies could hire people to manage these units. McDonald's, for example, could 
hire managers for its thousands of restaurants around the world. But effectively managing and monitoring far-flung operations can prove challenging. Being successful in the restaurant business requires attention to detail and often some degree of adaptation to local tastes and economic conditions.

Franchising solves this problem through incentives. Because the franchisees retain the residual profits of the units that they own and manage, they have strong incentives to operate efficiently and effectively and to adapt their operations as necessary to local conditions (Brickley and Dark 1987; Sorenson and Sørensen 2001).

South Africa's public hospitals and clinics have struggled with absenteeism and poor morale. Giving the nurse-owners strong incentives to provide high-quality care ensures that Unjani Clinics do not suffer a similar fate. Being business owners probably also gives these nurses a sense of pride and added status in their local communities, further motivating their effort through social incentives.

Franchises have also become popular because they offer the franchisor a second advantage: capital efficiency. By distributing ownership across the franchisee owner managers, franchisors can grow faster than they could if they owned all of their units (Oxenfeldt and Kelly 1969). Franchised chains can effectively draw not just on the resources of the central organization, but also on the personal resources of all of their franchisees.

Unjani Clinics expect to benefit from a similar type of financial efficiency. The combination of cash flow from royalties, the absence of most personnel costs (because they do not need to pay salaries to the nurses), and the ability to move assets off of the balance sheet as Unjani transfers clinics to the nursepreneurs should allow Unjani to scale rapidly.

Where else might these social franchises flourish? Although Unjani seems a relatively rare animal at the moment, many types of social organizations might learn from it. The franchise structure seems particularly well suited to situations in which the quality of the social service depends on personalization and on attention to detail. Education and child care, for example, come immediately to mind.

In fact, at least one organization has already been pursuing something similar in child care. The Early Care Foundation (ECF) trains women in the townships in South Africa to own and manage their own daycare centers. ${ }^{1}$ Although the ECF does not brand these centers, it does provide certification for these women, as a type of quality assurance for parents. These centers provide both income to the women running them and high-quality childcare to those living in the townships.

But social franchises also have their limitations. The strong incentives associated with the structure depend on a tight connection between profits and service quality. In the social sector, the beneficiary often does not pay for the service, loosening this connection. But social sector organizations might find solutions to this issue. For example, providing cash transfers or vouchers to beneficiaries that would allow those beneficiaries to choose and pay their service providers-such as the voucher systems developed for education in some states in the United States-might reintroduce this profit-quality connection.

A more binding constraint may come in terms of the nature of the organizational problem being solved. Franchises promote effort and innovation. They can therefore excel at providing high-quality services. But those same strong incentives discourage coordination and standardization (Sorenson and Sørensen 2001). Franchises therefore may prove less useful in settings where consistency matters most or which involve joint production.

Unjani's clinics can operate almost completely independent of one another. But imagine an organization trying to develop and enforce environmental standards. If organized as a social franchise, the strong incentives inherent in the organizational form might well encourage impasses, inconsistency, and possibly even outright fraud.

Many hotel and restaurant chains have mitigated this problem to some extent through monitoring. Unannounced visits by secret shoppers, for example, can determine whether franchisees have been adhering to the standards set by the franchisor. But, of course, the more the franchisor has to monitor and manage its franchisees, the less efficient this organizational animal becomes.

Authors' contribution OS wrote this essay. He also read and approved the final manuscript.

\section{Declarations}

Competing interests The authors declare that they have no competing interests.

Open Access This article is licensed under a Creative Commons Attribution 4.0 International License, which permits use, sharing, adaptation, distribution and reproduction in any medium or format, as long as you give appropriate credit to the original author(s) and the source, provide a link to the Creative Commons licence, and indicate if changes were made. The images or other third party material in this article are included in the article's Creative Commons licence, unless indicated otherwise in a credit line to the material. If material is not included in the article's Creative Commons licence and your intended use is not permitted by statutory regulation or exceeds the permitted use, you will need to obtain permission directly from the copyright holder. To view a copy of this licence, visit http://creativecommons.org/licenses/by/4.0/.

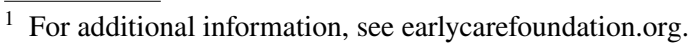




\section{References}

Brickley JA, Dark FH (1987) The choice of organizational form: the case of franchising. J Financ Econ 18:401-420

Caves RE, Murphy WF (1976) Franchising: firms, markets and intangible assets. South Econ J 42:576-586

Oster SM (1992) Nonprofit organizations as franchise operations. Nonprofit Manag Leadersh 2:223-238

Oxenfeldt AR, Kelly AO (1969) Will successful franchise systems ultimately become wholly-owned chains? J Retail 44:69-87
Sorenson O, Sørensen JB (2001) Finding the right mix: franchising, organizational learning, and chain performance. Strateg Manag J 22:713-724

Publisher's Note Springer Nature remains neutral with regard to jurisdictional claims in published maps and institutional affiliations. 